\title{
DRIM を用いた底質の分級制御に関する基礎的研究
}

\author{
小野信幸* ・ 入 江 功**・迫田史顕***・緒方 菊****
}

\begin{abstract}
歪んだ砂れん断面をもち漂砂を一方向に制御する機能を持つ歪み砂れんマット (DRIM) を利用して，覆砂などによる底質 改善策を施した人工干潟を沖側の泥土と混合することのない，いわば質の高い状態で維持する方法を検討するため，DRIM 上の底質分級の基礎的特性を固定床実験により調べた. その結果, DRIM 上では底質粒径の違いによる分級は生じるものの, 様々な波に対して制御を意図した方向へ底質を輸送することが可能であることが確認され，ある水深位置を境にDRIM の制 御方向を変えることで, 覆砂材料の沖への流出を防ぐと同時に，沖側からの泥土の侵入を抑制するといった底質混合の防止 が可能なことが示された。
\end{abstract}

\section{1.はじめに}

干潟海岸は，多様な生物の生育・生息の場を提供し， また，高い水質浄化機能を有する場として沿岸環境に とって非常に重要である.しかし近年, 沿岸域開発に伴 う干潟の環境悪化や埋立て等による干潟の喪失が問題視 され, 水質・底質の悪化した干潟を耕転したり, 覆砂に より人工干潟を造成するなどの干潟再生事業が各地で試 みられて扔り，こうした人工的な環境改善策とその効果 に関する研究・調査も活発になされている。

本研究は, 環境改善の施された人工干潟や人工海浜を 質の高い状態で維持する方法を検討するものである．例 えば，泥質干潟上に覆砂により造成された人工干潟にお いては, 覆砂後の砂浜にシルト・泥土が徐々に堆積して 底質が悪化することが問題となる，著者らは，これまで 図一1に示すような形状の漂砂を一方向に制御する機能 を有する歪み砂れんマット (Distorted Ripple Mat； DRIM）を沖浜帯に設置して養浜砂の流出を阻止する工 法の有効性を確認してきた (小野ら，2001，2002；山口 ら，2002）。これを，図一2のように覆砂により造成され た人工干潟の前方に設置すれば, 覆砂材料の沖への流出 を防ぎつつ泥土の覆砂上への堆積を防ぐため, 泥質干潟 上の砂浜を「質の高い状態」で維持可能になると考えた. 本研究は，このような底質の分級制御法を確立すること を念頭におき, その第一段階として, 粒度の異なる砂に 対するDRIM 上での分級特性について調べた。

\section{DRIM 上の底質分級特性}

覆砂により人工干潟を造成する場合に限らず，一般の 養浜工に扔いても, 養浜材料の粒度特性は人工海浜の 「質」に大きく影響する要素である。 そのため, 砂留構造 物の設置により特定の粒径域の底質（例えば粗砂）のみ が沖へ流出するといったことは生じてはならない. そこ

* 正 会 員 博 (工) 九州大学助手 大学院工学研究院環境都市部門

** 正 会員 工 博 九州大学教授 大学院工学研究院環境都市部門

*** 学生会員杂大学大学院工学府海洋システム工学専攻

**** 学生会員詶大学大学院工学府海洋システム工学専攻

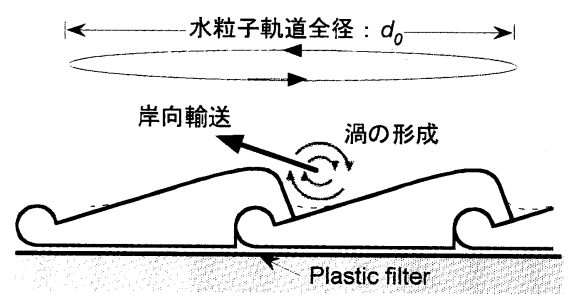

図一1 DRIM の形状と底層流の制御機構

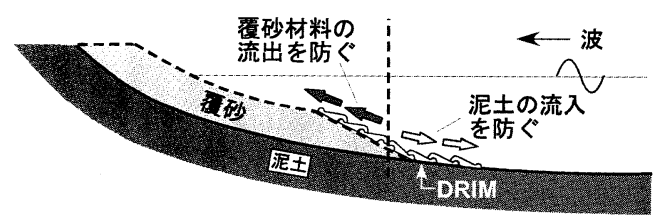

図一2 DRIM による人工干潟の保全方法の概念図

でまず，岸向きに漂砂制御するように設置された DRIM 上での底質の分級過程を調べる実験をおこなった。

\section{(1) 実験方法}

実験は, 図一 3 に示すような長さ $28 \mathrm{~m}$, 高さ $0.5 \mathrm{~m}$, 幅 $0.3 \mathrm{~m}$ の 2 次元造波水路の一端に設けた一様勾配 $(1 / 10)$ の斜面上にモルタルで成型した固定床歪み砂れんを設置 し, 一様水深部の水深を $35 \mathrm{~cm}$ に設定しておこなった。 歪み砂れんの形状は, 正弦波形で近似した砂れん形状(砂 れん波長 $\lambda=5.5 \mathrm{~cm}$, 波高 $\eta=1.0 \mathrm{~cm}$ )を砂れんの峰一谷 間の比が $1: 3$ となるように歪めたもので, 図一1 亿示す DRIM の表面形状の元になったものである. DRIM は, 波の通過により砂れん峰の両側に形成される渦の規模が 異なることにより底層の流れを一方向に制御する機能を もつ.

実験は砕波点より沖側に位置する $2 つ$ 砂れんの谷に 底質を $20 \mathrm{~g}$ づつ投入して波を一定時間作用させた後, 沈 殿した底質を砂れんの谷毎に採砂機により回収し，炉乾 燥後の重量を測定して底質の分散移動状況を調べた。底 質には粒径 $0.2 \mathrm{~mm}$ と $0.8 \mathrm{~mm}$ の軽量物質のメラミン (比重 $=1.5$, 沈降速度はそれぞれ $0.91 \mathrm{~cm} / \mathrm{s}$ と $4.32 \mathrm{~cm} /$ 


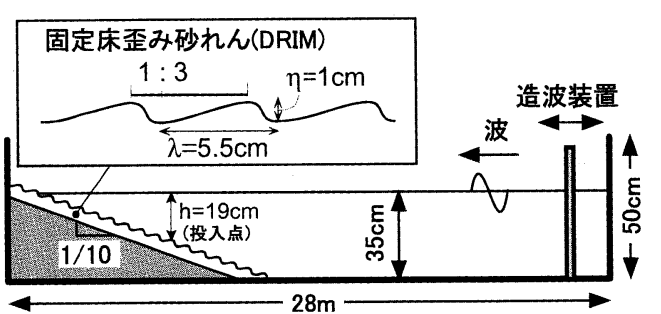

図-3 実験装置

表一 1 入射波と底質投入点の設定条件

\begin{tabular}{c|c|c|c|c|c}
\hline $\begin{array}{c}\text { 沖波波高 } \\
H_{0}(\mathrm{~cm})\end{array}$ & $\begin{array}{c}\text { 周期 } \\
T(\mathrm{~s})\end{array}$ & $\begin{array}{c}\text { 波形勾配 } \\
H_{0} / L_{0}\end{array}$ & $\begin{array}{c}\text { 水深 } \\
h(\mathrm{~cm})\end{array}$ & $\begin{array}{c}\text { 流速振幅 } \\
u_{b}(\mathrm{~cm} / \mathrm{s})\end{array}$ & $\begin{array}{c}\text { 波と砂れん } \\
d_{0} / \lambda\end{array}$ \\
\hline 4.6 & 1.8 & 0.01 & 19 & 16.4 & 1.7 \\
\hline 6.1 & 1.5 & 0.02 & 19 & 19.6 & 1.7 \\
\hline 7.7 & 1.3 & 0.03 & 19 & 22.7 & 1.7 \\
\hline
\end{tabular}

$\mathrm{s}\left(15^{\circ} \mathrm{C}\right)$ ) を用い（以下，それぞれ細砂，粗砂と呼ぶ）, 単一粒径のみと混合粒径（細砂と粗砂を $50 \%$ ずつ混合） で投入した場合について実験した。混合粒径砂を投入し た実験では，砂れんの谷毎に回収した底質を $0.425 \mathrm{~mm}$ のふるいにかけ，それぞれの細砂・粗砂の含有量を調べ た。 入射波は，表一1に示す沖波波形勾配 $\left(H_{0} / L_{0}\right)$ が異 なる 3 種類で，底質の投入点水深 $(h=19 \mathrm{~cm})$ における 水粒子軌道径と砂れん波長の比 $\left(d_{0} / \lambda\right)$ が 1.7 になるよう に設定した。これは，波により移動床上に砂れんが形成 されるときと同じ条件であり, かつ DRIM の底層流制御 機能が最も高くなる条件（武若ら，1998）でもある.

\section{(2) 実験 結 果}

図一 4 に，混合粒径砂を投入して波(沖波波高 $H_{0}=6.1$ $\mathrm{cm}$, 周期 $T=1.5 \mathrm{~s}$ )を作用させて $30,60,120$ 秒後の底 質分散状況で, 混合砂中の細砂と粗砂それぞれの含有量 を示す. 図より，時間の経過とともに細砂と粗砂の分級 が生じていることがわかる。しかし，その移動方向はど ちらも岸向き(漂砂制御を意図した方向) であり, 最終 的に砕波点付近に底質が集まる傾向であった。

図一5 は 3 種類の入射波に対する細砂と粗砂の重心位 置の時間変化をそれぞれ単一粒径砂・混合粒径砂として 投入した場合を比較したものである.混合砂中の細砂・ 粗砂の重心移動速度は単一粒径砂のみを投入した場合と ほぼ同等であるが，細砂については混合粒径砂の場合の 重心移動速度が単一砂の場合に比べて若干小さくなって いる．これは，本実験では固定床上に少量の底質を投入 して波を作用させているので顕著ではないが，混合砂の 場合に細砂が粗砂の層の下側にもぐり込んで移動が抑制 されるといういわゆるアーマリング効果が生じたためと 考えられる。

図一6 は，底質の投入点 (水深 $19 \mathrm{~cm}$ ) における DRIM 上の平均流速 $U$ の鉛直分布を 3 種類の入射波に対して

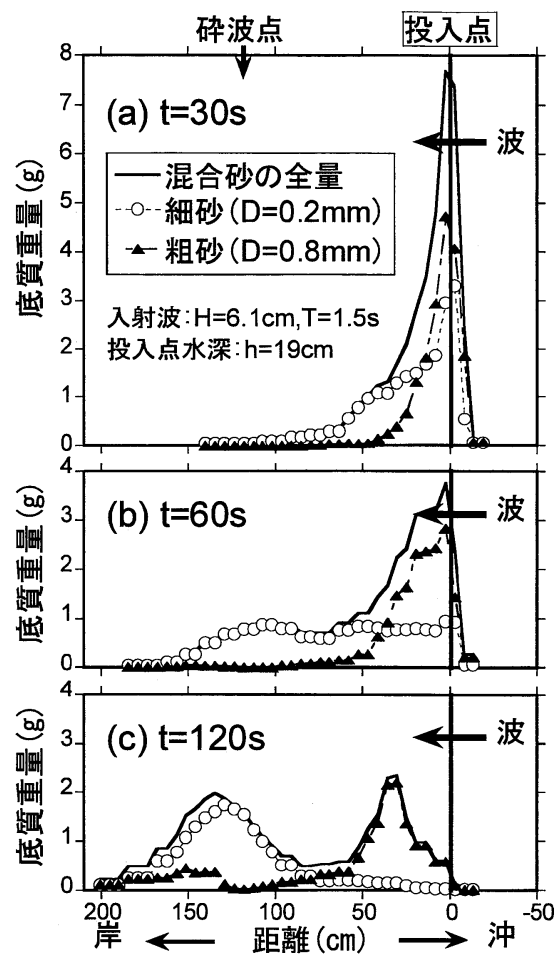

図-4 混合砂の分散移動状況 $\left(H_{0}=6.1 \mathrm{~cm}, T=1.5 \mathrm{~s}\right)$

示したものである.横軸は底面流速振幅 $u_{b}$ で無次元化し た平均流速 $U / u_{b}$, 縦軸は水深で無次元化した砂れん峰か らの高さ $z / h$ である.また, 図中には実験中に目視観察に より測定した細砂・粗砂それぞれの浮遊砂雲の巻き上が り高さを同時に示している. 図のように，どの波の条件 に対しても, 底面付近には DRIMにより制御された岸向 きの平均流が生じ, その流れが生じている高さ $\delta$ は, 細 砂と粗砂の浮遊砂雲が巻き上がる高さよりも高かった。 そのため, 本実験では細砂・粗砂ともに岸向きに輸送さ れたものと考朰れる.

（3）DRIM 上の分級機構と漂砂制御効果

実験で観察された DRIM 上の底質分級過程を図一7 に模式的に示した. 底面付近の流れが沖向きの時には, 細砂は浮遊しながら, 粗砂は転がり落ちるように DRIM の谷へ運ばれていた，流れが沖向きから岸向きへと反転 する位相では, 細砂・粗砂とも渦に巻き込まれるが, 粗 砂の一部はそこで沈降していた，その後流れが岸向きの 時には，渦に巻き込まれていた砂は渦の放出とともに浮 遊し, 岸向きへ輸送される。しかし, その場合も粗砂は すぐに沈降して底面に落ちるが, 細砂は粗砂よりも沈降 速度が遅いため, より岸側へと運ばれていた。こうして, DRIM 上に置かれた底質は時間とともに分級されてい く.このような現象は，振動流下における非対称砂れん 上の混合粒径砂の分級機構を詳細に調べた鈴木ら (1994) 

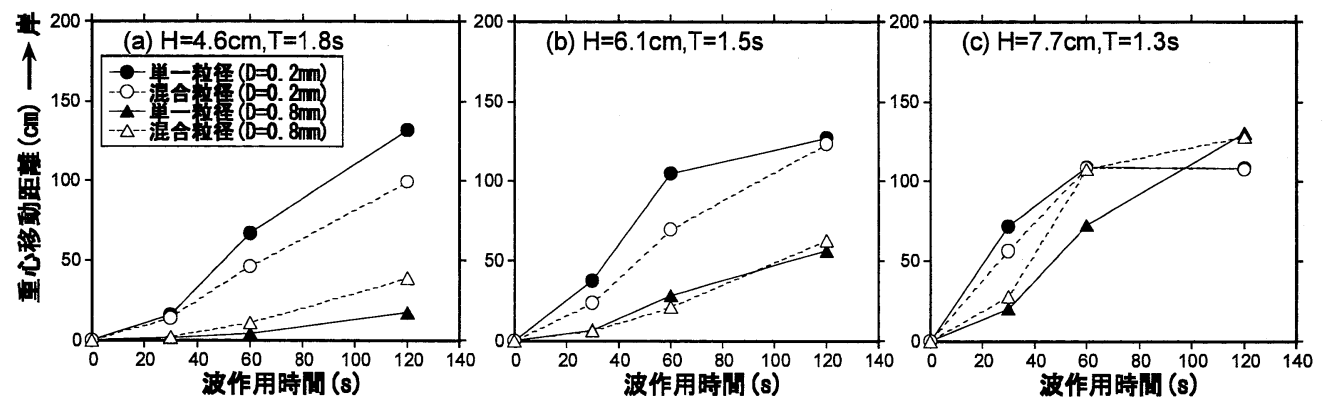

园一5 底質分布の重心位置の時間変化

(a) $\mathrm{H}_{0}=4.6 \mathrm{~cm}, T=1.8 \mathrm{~s}$

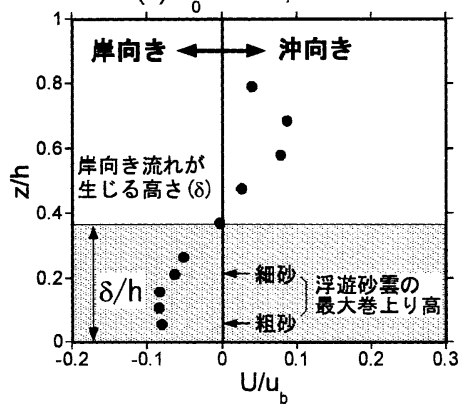

(b) $H_{0}=6.1 \mathrm{~cm}, T=1.5 \mathrm{~s}$

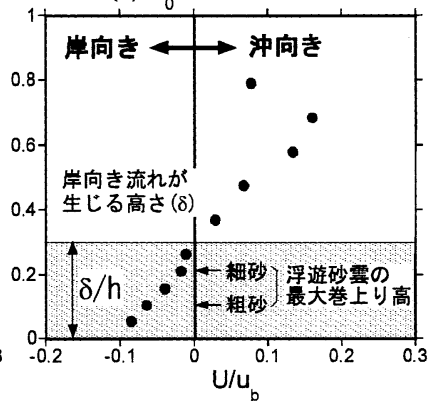

(c) $\mathrm{H}_{0}=7.7 \mathrm{~cm}, \mathrm{~T}=1.3 \mathrm{~s}$

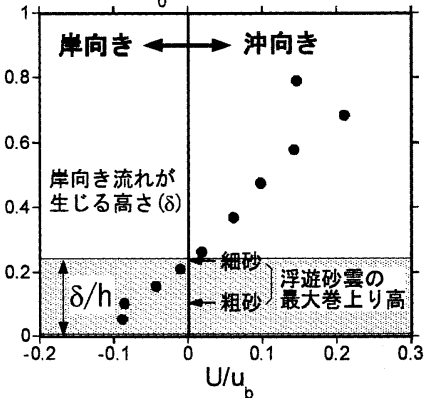

図一6 平均流速分布と浮遊砂雲の巻上げ高

の観察結果と非常に類似していた。

このように，DRIM 上で底質の分級は生じるものの， 本実験の範囲では細砂・粗砂の移動方向はともに岸向き (DRIM により制御される方向)であり，それは図一6に 示したように, 制御された底層流が生じる高さ $\delta$ と底質 が巻き上がる高さに深く関連すると考えられる。そこで, 様々な波の条件に対する $\delta$ と細・粗砂の巻上げ高さの関 係について調べた結果を图一 8 に示した. 図一 8 の $\delta$ は, 武若ら（1998）がレーザー流速計により測定した DRIM 上の流速デー夕を再整理してプロットしたものである. 流速デー夕は, 砂れん峰上の水深が $29 \mathrm{~cm}$ になるように 水平に敷き詰められたDRIM 上において, 波高 $H=$ $5 \sim 9 \mathrm{~cm}$, 周期 $T=0.8 \sim 2.0 \mathrm{~s}$ の範囲の波作用下で測定 されている. また，図中に示す浮遊砂雲の巻き上げ高さ は, 本実験で使用した軽量物質の細砂と粗砂に対して柴 山ら（1993）の浮遊砂濃度分布の推定式を適用し, 浮遊 砂濃度を水面まで鉛直積分した值の $95 \%$ の浮遊砂量と なる高さを求めたものである. 図は, 横軸に $d_{0} / \lambda$ をと てプロットしているが, 相当広範囲の波の条件に対し, DRIM の制御効果が及ぶ範囲は浮遊砂雲が巻き上がる 高さより高いことがわかる．実験で用いた底質が軽量物 質のメラミンであり，砂よりも巻き上がりやすい条件に あることを考慮すると DRIM 上の底質はほほ DRIM に より制御を意図した方向に輸送されるものと考えられ
る.

\section{3. 分級制御法に関する実験}

\section{（1） DRIMによる分級制御}

次に，図一1のようにある水深を境に制御方向を変え て設置することにより，覆砂材料の沖への流出を防止す ると同時に，沖からの泥土の流入を抑制するといった分 級制御が可能かどうかを調べる実験をおこなった。実験 は水深 $20 \mathrm{~cm}$ を境にその岸側で岸向き制御, 沖側で沖向 き制御するように DRIM を設置し，表一1 と同じ波を作 用させた。図一9 は，波高 $6.1 \mathrm{~cm}$, 周期 $1.5 \mathrm{~s}$ の波を作用 させたときの制御方向分岐点付近の平均流速分布を測定 した結果を示したものである。図より，底面付近の流れ は分岐点より砂れん一波長分離れると確実にDRIM の 制御方向と同じ向きとなっていることがわかる.

図一10 は, 図一9 と同じ波の条件に対し,制御方向分岐 点の砂孔ん 2 波長分岸側に粗砂を， 2 波長分沖側に細砂 を投入してそれぞれの分散移動状況を調べた結果であ る。底質はそれぞれ意四した制御方向に移動し，この結 果は，DRIMによりある水深を境として底質の移動方向 を変えるといった分級制御が可能なことを示すと考えら れる。

\section{（2）泥土の流入防止効果}

これまでに述べた実験結果は，主に底質が砂である場 

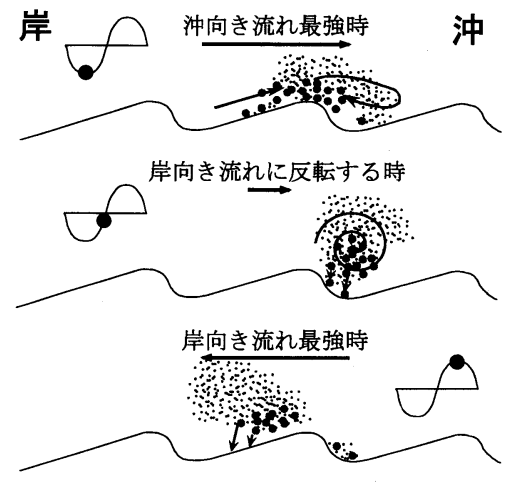

沖向き流れに反転する時

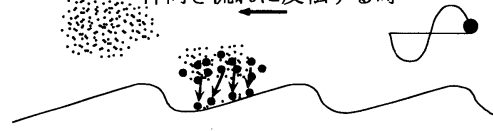

図一7 DRIM 上の底質分級機構の観察結果

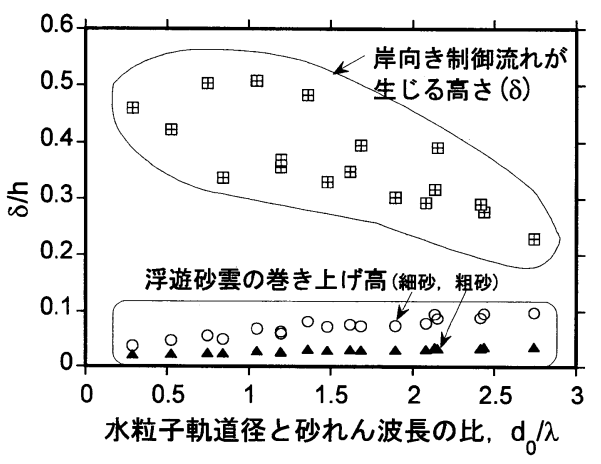

図一8 制御高 $\delta$ と浮遊砂雲の巻き上がり高さ

合を対象としたもので，その場合にはDRIM の漂砂制御 効果がよく機能することを確認した。しかし，人工干潟 の底質悪化の主要因は有機物を過剩に含んでへドロ化し たシルトや粘土のような微細粒子が堆積するためと考え られる．また，波・流れに対する泥土と砂の移動特性は 大きく異なるため, DRIM の漂砂制御効果が泥分の主な 移動形態であるフルードマッドを形成した状態に対して 機能するのかを調べる必要がある，以下では，この点に ついて調べた実験について述べる。

フルードマッドと DRIM の効果を調べる実験は, 著者 ら（2003）が航路埋没対策を検討するために作成した水 槽を用いておこなった. 図一11 に実験装置の模式図を示 す. 水槽は長さ $3 \mathrm{~m}$, 高さ $1 \mathrm{~m}$, 幅 $0.2 \mathrm{~m}$ で, 水深 $40 \mathrm{~cm}$ となるように水を張り, 図中の Gate A と B を閉じた状 態で底質を投入して十分擋汼し, その後自由沈降させて 所定の厚さ $h_{f}$ のフルードマッドを形成させた後, Gate $\mathrm{A}$ と B をすばやく引き上げてフルードマッドを流動さ せる仕掛けとなっている。実験では, フルードマッドを

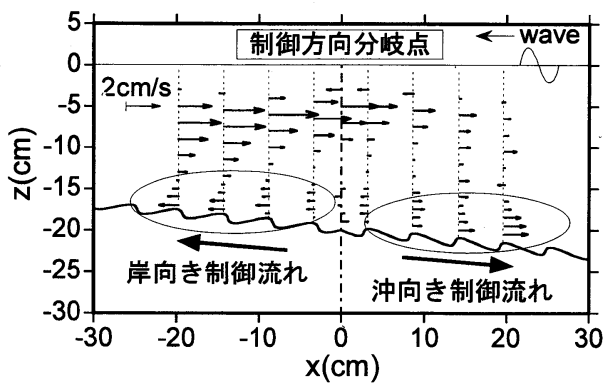

図一9 分岐点周辺の平均流速の空間分布

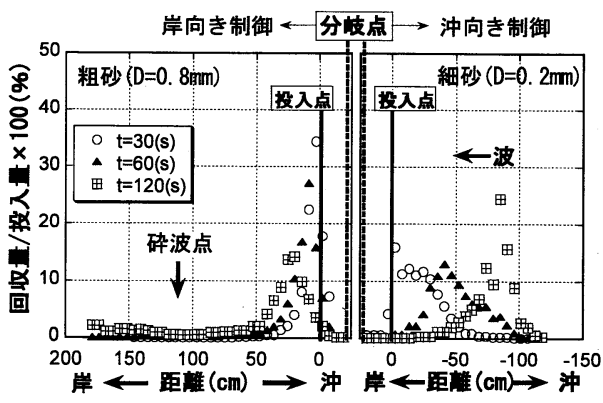

図-10 分級制御の底質移動実験結果

形成させる場所と航路を模した落ち込み部の間に DRIM の模型を設置し, これがフルードマッドの流動を どの程度阻止するかについて調べた。

图一12 は, Gate B を引き上げてから 30 秒後のフルー ドマッドの流動状況を撮影したもので, 左上は構造物を 設置しない場合, 左下は高さ $10 \mathrm{~cm}$ の逆 $\mathrm{T}$ 型堤, 右上は 高さ $10 \mathrm{~cm}$ の台形堤, 右下は高さ $5 \mathrm{~cm}$ の DRIM で上面 に 3 波長分の DRIM 形状を整形したものを設置してい る.フルードマッドを形成する底質には, 平均粒径 0.6 $\mu \mathrm{m}$, 比重2.6, 白色のカオリナイトを使用し, 一様に擋汼 したときの濃度が $20 \mathrm{~g} / 1$ となるように底質を投入して 厚さ $h_{f}=10 \mathrm{~cm}$ のフルードマッドを形成させた． DRIM の漂砂制御効果は, 波の作用により発揮されるので, こ の実験では周期 3 秒, 振幅 $3 \mathrm{~cm}$ で泥止め構造物を左右 に振動させるとともに, 潮流による流れの効果を考虑す るためにポンプにより図中右から左へ断面平均流速 1 $\mathrm{cm} / \mathrm{s}$ の一方向流れを作用させた条件で比較している （ただし，構造物なしの場合は流れを起こしていない）。

図一12 の写真を比較すると, 構造物を置かない場合は 大量の泥土が流動し, 水槽の落ち込みへと進入したこと がわかる. 構造物を置いたケースを相互に比較すれば, 構造物を越えた泥土の量は $T$ 型堤 $>$ 台形堤 $\fallingdotseq \mathrm{DRIM}$ ある. 図一13 は, 図一12 のように撮影された画像から， 图一11の斜線部で示す測定領域の輝度を読み取って浮 泥濃度に換算し, 測定領域内の泥土量の時間变化を推定 


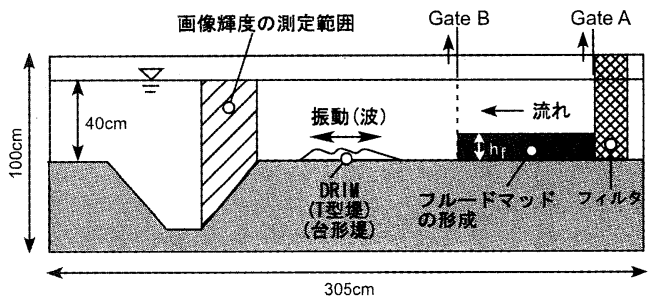

図一11 フルードマッドの流入制御実験の装置図
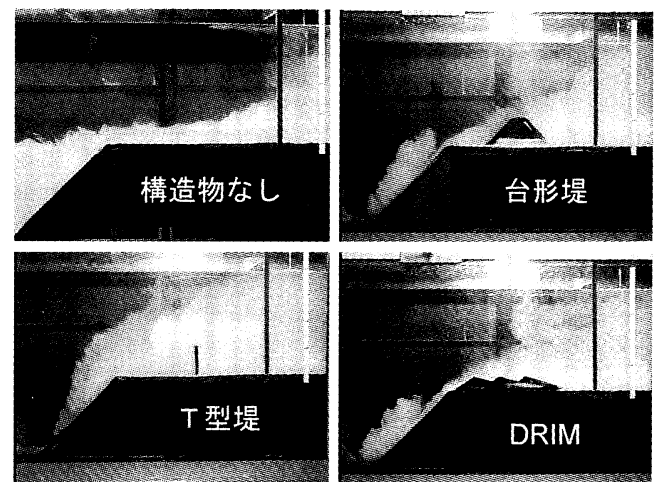

図-12 浮泥の流動状況（30 秒後）

した結果である. 写真の比較結果と同様に，DRIM と台 形堤がほぼ同じ変化を示しており, DRIM は台形堤の半 分の高さであるにも関わらず台形堤とほぼ同等の効果が 見られる。これは，DRIM が誘起する底層流が泥土に対 しても有効であることを示すものと考えられる.

\section{4. ま と め}

波作用下において底層流を一方向に制御可能な DRIM を用いて，人工干潟を質の高い状態で維持する方 法を検討するために，粒度が異なる底質に対するDRIM の漂砂制御効果を調べる基礎的実験をおこなった。その 結果, 底質粒径の違いにより DRIM 上で底質の分級は生 じるものの，様々な波に対して制御を意図した方向へ底

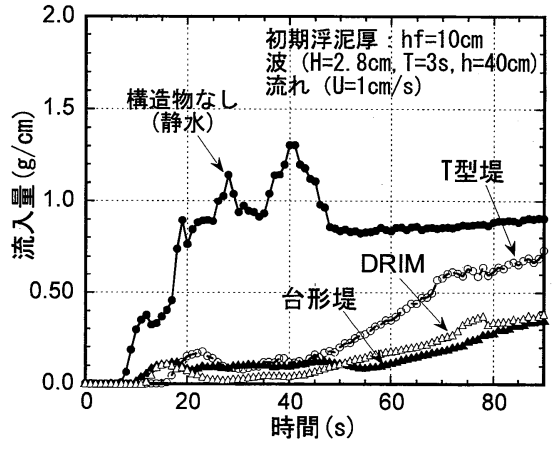

図一13 流入制御効果の比較

質が輸送されることが確認された，また，ある水深を境 にDRIM の制御方向を変えることで, 覆砂材料の沖への 流出を防ぎつつ, 沖側からの泥土の侵入を抑制すると いった分級制御が可能なことが示された。

\section{参 考 文 献}

小野信幸・入江 功・横田雅紀（2001）：歪み砂れんによる海浜 断面安定化工法に関する研究, 海岸工学論文集, 第 48 巻, pp. 676-680.

小野信幸・入江 功・緒方 菊・山口 洋 (2002)：ピーチ开イ クルを考慮した養浜断面の安定化に関する研究, 海岸工学論 文集, 第 49 巻, pp. 626-630.

小野信幸・入江 功・竹内伸夫・青木 聡・ Rahman Hidayat (2003): 複列潜堤によるシルテーションの高能率防止策に 関する研究, 海岸工学論文集, 第 50 巻, pp. 516-520.

柴山知也・Rattanapitikon, Winyu (1993)：砕波帯を含む浮遊砂 濃度の鉛直分布の評価, 海岸工学論文集, 第 40 巻, pp. 306-310.

鈴木高二郎・渡辺 晃・磯部雅彦・Mohammad Dibajinia（1994)： 振動流下における混合粒径底質の移動現象について, 海岸工 学論文集, 第 41 巻, pp. 356-360.

武若 聡・入江 功・内田雅洋・坂本寛和・渡辺桂三 - 小野信幸 (1998)：歪み固定砂れんによる岸沖漂砂の制御とその最適 寸法・形状に関する検討, 海岸工学論文集, 第 45 巻, pp. 506-510.

山口 洋・小野信幸・入江 功・申 承鎬・村瀬芳満 (2002)：歪 み砂れんマットによる 3 次元的漂砂制御に関する実験, 海岸 工学論文集, 第 49 巻, pp. 621-625. 